\title{
Predictors of Indulgence in Procrastinating Behaviour: Demographic Variables and Self-Esteem
}

\author{
Richard A. Adu*
}

\section{ABSTRACT}

The study investigated demographic variables and self-esteem as predictors of indulgence in procrastinating behaviour. It utilized a correlation survey design involving two hundred and forty two sampled male (114) and female (128) civil servants in Ibadan, Oyo State, Nigeria. Data were collected from the sample using two scales. All the scales were re-validated. Seven hypotheses were tested. The results of simple regression analyses showed that both age and self-esteem independently predicted indulgence in procrastinating behaviour. Likewise, the results of t-test analysis revealed that marital status had significant influence on indulgence in procrastinating behaviour and that the single respondents indulged more in procrastination than married respondents. Further, the results of analysis of variance indicated that educational qualification had significant effect on indulgence in procrastinating behaviour. Multiple regression analysis results revealed that self-esteem, gender, age, marital status, educational qualification, and work experience jointly predicted indulgence in procrastinating behaviour and that only self-esteem and educational qualification independently predicted procrastination. The findings indicate that, self-esteem, and the listed demographic variables are significant predictors of indulgence in procrastinating behaviour among employees in this investigation. The study recommends that management and employers of labour should take cognizance of these predictors in their recruitment, training and development programs to enhance employees' output and lessen indulgence in procrastinating behaviour.

Keywords: Demographic variables, self-esteem, indulgence in procrastinating behaviour

\section{INTRODUCTION}

Procrastination is one of the numerous social phenomena that have since been neglected by the researchers in work organization. Procrastination like so many other psychological concepts has been variously defined. Different scholars from different backgrounds have offered their own meaning of the term and these different attempts by scholars to refine our understanding of procrastination have been complementary rather than contradictory. It should be noted, however, that one or more core or essential elements such as postponing, delaying, or putting off of a task or decision, in keeping with the term's Latin origins of pro, meaning "forward, forth, or in favour of,"

\footnotetext{
*Department of Psychology, University of Ibadan, Ibadan, Nigeria.
}

(c) 2014 A. Adu; licensee IJIP. This is an Open Access Research distributed under the terms of the Creative Commons Attribution License (http://creativecommons.org/licenses/by/2.0), which permits unrestricted use, distribution, and reproduction in any Medium, provided the original work is properly cited. 
-and crastinus, meaning "of tomorrow" (Klein, 1971) are recurrent themes in most definitions of procrastination.

Building on this foundation, an individual is said to procrastinate when she/he delays beginning or completing an intended course of action (Beswick \& Mann, 1994; Ferrari, 1993a; Lay \& Silverman, 1996; Milgram, 1991; Silver \& Sabini, 1981). This is a useful distinction, as there are thousands of potential tasks that one could be doing at any time, and it becomes cumbersome to think that one is putting them all off. The distinction also separates procrastination from simple decision avoidance (Anderson, 2003), with which people's original intention is to delay.

To Solomon and Rothblum, 1984 (as cited in Howell \& Watson, 2007) procrastination is described as "the tendency to delay initiation or completion of important tasks to the point of discomfort". Others state that procrastination refers to an inability to draw from past experience, leading procrastinators to underestimate the difficulty of the task at hand (Lay, 1986).

Popoola (2005) considers procrastination as a dispositional trait which has cognitive, behavioural and emotional components (as cited in Akinsola, 2007).

In the final analysis, procrastination is most often considered to be the irrational delay of behaviour (Akerlof, 1991; Burka \& Yuen, 1983; Ellis \& Knaus, 1977; Silver \& Sabini, 1981), which reveals the dictionary meaning: "defer action, especially without good reason" (Oxford English Reference Dictionary, 1996). Being irrational involves choosing a course of action despite expecting that it will not maximize your utilities, that is, your interests, preferences, or goals of both a material (e.g., money) and a psychological (e.g., happiness) nature. Combining these elements suggest that to procrastinate is to voluntarily delay an intended course of action despite expecting to be worse off for the delay (Steel, 2007).

\section{STATEMENT OF PROBLEM}

Many organizations today are striving to maintain their competitive advantage over their competitors. These organizations depend heavily on their ever committed employees in order for them to accomplish this great fit. It is not surprising that, these employees are sometimes found to procrastinate in doing their assigned work tasks that are aimed to assist their organizations in maintaining their competitive edge over their competitors. This study therefore, is set to assess self-esteem and demographic variables as predictors of indulgence in procrastinating behaviour among employees.

\section{OBJECTIVES OF STUDY}

In order to test the hypotheses formulated for this study, the specific objective is to examine whether self-esteem will independently predict indulgence in procrastinating behaviour, and to critically evaluate whether demographic variables and self-esteem will jointly predict indulgence in procrastinating behaviour significantly.

\section{THEORETICAL BACKGROUND}

Appraisal-anxiety theory proposes that procrastination is a function of cognitive evaluation of task by the procrastinators (Lazarus and Folkman, 1984). According to the theory, when an individual is presented with challenging task (say writing an 'award winning"' research proposal 
or methodology), the individual first evaluates whether she/he has the capability to cope with the task. If the individual perceives that she/he cannot successfully deal with the task, then the outcome is feelings of anxiety and the behavioural response of escape or avoidance behaviours (that is procrastination) (Lazarus and Folkman, 1984). Appraisal-anxiety theory emphasizes the role of self-efficacy (a form of situational self-esteem Korman, 1970, and 1976) in procrastination. According to the theory, employees will indulge in procrastinating behaviour when they perceived that they lack the requisite skills to get task at hand to be accomplished. For example, an employee may be well talented and always willing to do his/her work but do not believe in his/her ability to successfully perform the job and as a result of this, he/or she kept postponing doing the job. The assertion of appraisal-anxiety theory is in line with the findings of Steel (2007) who found that low self-efficacy and low self-esteem are associated with procrastination. The theory has been able to show that employees procrastinate when they perceived that they lack the required skills to perform needed tasks they ought to perform.

One of the earliest attempts to explain the dynamics of procrastination was made by psychoanalytic theorists. Freud (1953) was the first who explained the avoidance behaviours with the role of anxiety. He stated that tasks are avoided primarily because they are threatening to the ego. Through delaying, the ego is protected from the risk of possible failure. Similarly, recently, Birder (1993) suggested that procrastination is a defence against impulses and separation. It is a result of psychologically or physically dangerous maturation and growth process. Hence, procrastinators can be seen as passive children who are hesitate to assert themselves actively. Nevertheless, one of the obvious problems with the psychoanalytic theory is its difficulty to empirically test (Ferrari et al., 1995).

One of the most popular theories about the origin of procrastination is that procrastination is a self-protection of fragile self-esteem (Burka \& Yuen, 1983; Tice, 1991). The theory proposed that performance is reflection of ability (efficacy) which is also a reflection of self-worth. This declaration reveals an equation among performance, ability and self-worth. Hence, failure at a task becomes an indicator of lack of efficacy and a low self-esteem. Consequently, the employees develop a fear of failure due to the emphasis placed on success in defining selfesteem and procrastination interrupts the equation. Since performance has been impaired by time constraints; performance does not equal ability and therefore does not equal self-esteem. In this way, procrastination serves as an ego defensive function. Hence, procrastination is used as a protective device by people with fragile self-esteem.

This approach again, reveals the important role of efficacy and self-esteem in employees' procrastination. Nevertheless, the theory is hard to verify.

In summary, there is some evidence to suggest that procrastination is a phenomenon that is wide in scope more than the way it had been traditionally discussed in the specific theories. The scope of procrastination should be expanded beyond the specifically focusing on anxiety, control, and motivation. Therefore, procrastination should be investigated by focused on an approach which covers possibly all related constructs. In this respect, the paper focused on the multiple predictors 
Predictors of Indulgence in Procrastinating Behaviour: Demographic Variables and Self-Esteem

of procrastinating behaviour by approaching self-esteem, age, gender, work experience, educational qualification, and marital status to understand procrastination more comprehensively.

\section{LITERATURE REVIEW}

Available literature regarding indulgence in procrastinating behaviour shows that much of the research is a recent endeavour. According to Knaus (2000), "'prior to 1979, procrastination received limited attention in the United States". As late as 2005, Ferrari, O'Callaghan and Newbegin wrote that "no systematic study has examined global prevalence of chronic procrastination- purposeful delay in starting or completing tasks". Obviously, every person indulges in procrastinating behaviour on occasion. An individual may put forward doing something he/she doesn't finds pleasant or that he/she feels forced by others to do (a form of mini-rebellion against authority). But, such delays do not make such individual a chronic procrastinator. According to Ferrari (2010), the chronic procrastinator, accepts delay as a maladaptive way of life across a variety of settings. Chronic procrastinators delay at home, school, work, in relationships with family and friends, in how they decide to do (or not do) tasks.

Some scholars noted that procrastination as a problem extends far beyond academic institutional settings: they admitted that procrastination chronically affects $15-20 \%$ of adults (Harriott \& Ferrari, 1996; Steel, 2007). And it predicts decreased work (Ellis \& Knaus, in press; Robb, 1998, as cited in Knaus, 2000) and academic performance (Owens \& Newbegin, 1977, as cited in Knaus, 2000). Ferrari, O'Callaghan and Newbegin (2005) found that it is more likely to be reported by white collar as compared to blue collar workers (Hammer and Ferrari, 2002, as cited in Ferrari, O'Callaghan and Newbegin, 2005). Some eminent scholars reported that independent of fear of failure, self-efficacy and self-esteem are directly linked to procrastination and performance (Bandura, 1997; Burka \& Yuen, 1983; Judge \& Bono, 2001). Numerous results of studies show that the core of procrastination is impulsiveness and related traits such as low selfesteem, poor self-control and distractibility (Steel, 2011).

Guindon (2010) suggested that what individuals choose to do and the way they do it depend on their self-esteem. The conceptualizations of self-esteem have been inconsistent. Countless of studies (Beck et al., 2000; Eggens, van der Werf, \& Bosker, 2008; Klassen et al., 2008), for example, suggested self-esteem as the antecedent of performance; while others view it as consequent component. Some of the recent studies, on the other hand, suggested that self-esteem is a mediator between the emotions and behaviours.

Self-esteem has been considered an important contributing factor to the explanation of procrastination. It refers to judgments of global self-worth (Rosenberg, 1965). Burka and Yuen (1983, as cited in Özer, 2010) suggested that individuals procrastinate to protect their fragile sense of self-esteem. In the study conducted by Beswick et al. (1988), self-esteem was one of the three possible explanations for procrastination along with irrational beliefs. Flett, Blankstein, and 
Martin (1995) suggested that procrastinators suffer from lower level of self-esteem which cause to a general tendency to turn it in behaviour like task delay or avoidance that protect selfpresentation by providing an excuse for poor performance and negative outcomes. In this respect, numerous studies have found a significant inverse relationship between academic procrastination and self-esteem (e.g., Ferrari, 1994; Ferrari, 2001), whereby feelings of worthlessness cause to task avoidance that might results in failure (Ferrari, 2000).

The relationship between procrastinating behaviour and self-esteem has received considerable attention in the procrastination literature (Beck et al., 2000; Effert \& Ferrari, 1989; Ferrari, 2000; Solomon \& Rothblum, 1984), with the results showing negative correlation with procrastination. On the contrary to general findings, Beck, et al. (2000) did not find significant correlation between self-esteem and procrastination.

According to Steel (2007) procrastination appears to decrease with age ( $r=-.15)$. Likewise, U.S. Census Bureau (2000) found a significant negative relationship between age and procrastination. To Steel and Ferrari (2013), there is a significant association between procrastinating behaviour and young, single men with less education residing in countries with lower levels of selfdiscipline.

The expected influence of gender on procrastination is difficult to predict. Feingold (1994) study on gender differences and the related construct of self-control showed mixed results. Men may score higher, lower, or the same as women depending on the measure.

As per marital status in relation to academic performance several studies had showed that, married (men and women) undergraduates performed better compare to single (unmarried). For instance Smith and Naylor (2001) examined data of all the students who graduated from all the UK universities in 1993 and found that married students (men and women) do better than unmarried (single) students. In 2010, Al-Mutairi reported married students at the AOU outperforming their unmarried (single) counterparts and concluded that marital status plays critical role in predicting students' academic performance.

Conclusively, it must be emphasized that, self-esteem plays a vital role in employees' indulgence in procrastinating behaviour. At present, little or nothing has been done in regards to the influence of demographic variables on procrastinating behaviour. The current study examined the independent and joint influence of demographic variables and self-esteem on employees' indulgence in procrastinating behaviour.

\section{HYPOTHESIS}

1. Self-esteem will independently predict employees' indulgence in procrastinating behaviour significantly.

2. Employees' age will independently predict indulgence in procrastinating behaviour significantly. 
3. Gender will independently predict employees' indulgence in procrastinating behaviour significantly.

4. There will be significant difference between single and married employees' in their indulgence in procrastinating behaviour.

5. Educational qualification will have a significant effect on employees' indulgence in procrastinating behaviour.

6. Work experience will have a significant effect on employees' indulgence in procrastinating behaviour.

7. Self-esteem, age, gender, marital status, educational qualification, and work experience will jointly predict employees' indulgence in procrastinating behaviour significantly.

Findings of this study will add to scanty data on demographic factors in relation to indulgence in procrastinating behaviour and facilitate the effective utilization of demographic variables as human resource development tool. The study will also assist employees and researchers as well in fashioning out effective ways in surmounting impediments to performance, thus informing policy makers.

\section{METHOD}

\section{Design and setting}

This study utilized the correlational survey design; data on all variables were collected as they occurred in everyday work situation. The independent variables under consideration were demographic variables and self-esteem. The dependent variable was indulgence in procrastinating behaviour and this was measured based on each participant's score on Tuckman's (1991) 16-item procrastination scale.

The study was carried out among Oyo State civil servants working in the State Secretariat, Ibadan, Oyo State, Nigeria. The respondents were drawn from different cadres of civil servants junior, intermediate and senior cadres.

\section{Participants of the Study}

Two hundred and forty two (242) civil servants (male: 128 and female: 114) were conveniently sampled from five (5) different ministries (Trade, Investments and Cooperatives, Justice, Education, Women Affairs, Community Development and Social Welfare, and Lands and Housing) in Oyo State civil service, Nigeria. One of the inclusion criteria was that the participants must be above 18 years of age; this is simply because 18 is the constitutional adult age in Nigeria. Also participant must be able to read and write English, which is the official language in the country. One hundred and sixty two (66.9\%) of the respondents were married and $80(33.1 \%)$ of them were single. The respondents' ages ranged from 19 to 59 . Their mean age was $35.64(\mathrm{SD}=10.66)$. Three $(1.2 \%)$ of the respondent had primary school education, 22 (9.1\%) had Ordinary National Diploma (OND), 130 (53.7\%) had Higher National Diploma/Bachelor of Science Degree (HND/BSc.), and 17 (7.0\%) had Masters of Science Degree/Doctor of Philosophy (MSc./PhD). However, 3 (1.2\%) of the respondents did not 
indicate their academic attainment. Forty seven (19.4\%) of the respondents had spent less than one year in active service, $63(26.0 \%)$ between one and five years, $39(16.1 \%)$ between six and ten years, $22(9.1 \%)$ between eleven and fifteen years, $64(26.4 \%)$ sixteen years and more, finally, $7(2.9 \%)$ of the respondents did not indicate the number of year (s) they have spent in active service.

\section{Instruments}

Two validated scales were used for data collection on the variables of interest.

Demographic data: The demographic variables taped include sex, age, marital status, religion, educational qualification, and work experience.

\section{Self-esteem}

Self-esteem was measured with a 10-item self reported Likert Scale, developed by Rosenberg (1965). The scale has an alpha reliability of 0.90. A Cronbach's alpha of 0.68 was established with the present population. It is a 4-point scale, for items 1, 2, 4, 6, and 7: Strongly agree $=3$, Agree $=2$, Disagree $=1$, Strongly disagree $=0$, for items 3, 5, 8, 9, and 10 (which are reversed in valence): Strongly agree $=0$, Agree $=1$, Disagree $=2$, Strongly disagree $=3$ with a possible total of 30 (e.g. all in all, I am inclined to feel that I am a failure). An individual who scored within the mean or above the mean was regarded as having high self-esteem, while those who scored below the mean we're be considered to be low on self-esteem.

\section{Indulgence in procrastinating behaviour}

Tuckman (1991)'s procrastination scale (TPS16) was used to measure civil servants' tendency to indulge in procrastinating behaviour. This scale is a 35-item originally, 4-point, Liker-type scale with a reliability coefficient of 0.90 . Using factor analysis, Tuckman reduced this original 35item scale to 16 -item scale consisting of items that loaded 0.40 or higher with an alpha reliability of 0.86. Using the Tuckman's 16-item scale, a Cronbach's alpha of 0.69 was obtained for this current research. The 16-item takes lesser time to administer than the 35-item scale. The scale is anchored at " 1 " by "that's not me for sure" and at " 4 " by "That's me for sure" (e.g. I needlessly delay finishing jobs, even though they are important). The 16-item scale was used to determine civil servants' tendency to indulge in procrastinating behaviour. The scale ranged from 16-64. Participants who scored between 57 and 64 were said to be high on indulgence in procrastination, while those who scored 34-49 were regarded to be low on indulgence in procrastination.

\section{Sampling Procedure}

The study adopted a multistage sampling procedure. Different sampling technique was used at different points of the selection of participants and government ministries. The convenient 
sampling method was used to select the civil servants. A simple random sampling was used in selecting the government ministries and agencies.

\section{Data Analysis}

Data received from questionnaire distributed was coded and finally analyzed using IBMStatistical Package for Social Sciences (SPSS) version 20. Hypotheses 1, 2, and 3 were analyzed with the aid of Simple Regression Analysis. Hypothesis 4 was analyzed using Independent t-test statistics. Hypotheses 5 and 6 were analyzed with the aid of One-Way Analysis of Variance. Multiple Regression Analysis was finally applied on hypothesis 7.

\section{RESULTS}

This section presents the results of data analyses performed on the data collected.

Table 1: Summary of Simple Regression Analysis using Self-esteem to predict Indulgence in Procrastinating Behaviour

\begin{tabular}{|c|c|c|c|c|c|c|}
\hline Predictor & $\mathrm{R}$ & $\mathrm{R}^{2}$ & $\mathrm{~F}$ & $\beta$ & $\mathrm{t}$ & $\mathrm{P}$ \\
\hline Self-esteem & .22 & .05 & 12.67 & -.22 & 18.89 & $<.001$ \\
\hline
\end{tabular}

Hypothesis one which stated that, self-esteem will independently predict employees' indulgence in procrastinating behaviour significantly was confirmed $\left\{\mathrm{R}^{2}=.050, \mathrm{~F}(1,240)=12.67 ; \mathrm{p}<.001\right\}$. Observation of the beta value $(\beta=-.22)$ revealed further that, the higher the employees' indulgence in procrastinating behaviour the lower their self-esteem vice versa. Table 1 also showed that, $5.0 \%$ variance in respondents' indulgence in procrastinating behaviour was accounted for by the respondents' self-esteem.

Table 2: Summary of Simple Regression Analysis using Age to predict Indulgence in Procrastinating Behaviour

\begin{tabular}{|c|c|c|c|c|c|c|}
\hline Predictor & $\mathrm{R}$ & $\mathrm{R}^{2}$ & $\mathrm{~F}$ & $\beta$ & $\mathrm{t}$ & $P$ \\
\hline Age & .152 & .023 & 5.40 & -.152 & -2.32 & $<.05$ \\
\hline
\end{tabular}

Hypothesis two which stated that, employees' age will independently predict indulgence in procrastinating behaviour significantly was supported $\left\{\mathrm{R}^{2}=.023, \mathrm{~F}(1,240)=5.40 ; \mathrm{p}<.05\right\}$. This means that, age is a significant predictor of employees' indulgence in procrastinating behaviour. Table 2 indicated that, $2.3 \%$ variability in participants' indulgence in procrastinating behaviour 
was attributable to the participants' age. Again, observation of the beta value showed that, the higher the employees' age, the lower their indulgence in procrastinating behaviour vice versa.

Table 3: Summary of Simple Regression Analysis using Gender to predict Indulgence in Procrastinating Behaviour

\begin{tabular}{|c|c|c|c|c|c|c|}
\hline Predictor & $\mathrm{R}$ & $\mathrm{R}^{2}$ & $\mathrm{~F}$ & $\beta$ & $\mathrm{t}$ & $\mathrm{P}$ \\
\hline $\begin{array}{l}\text { Gender } \\
.05\end{array}$ & .103 & .011 & 2.55 & -.103 & -1.60 & $>$ \\
\hline
\end{tabular}

Hypothesis three which stated that, gender will independently predict employees' indulgence in procrastinating behaviour significantly was rejected $\left\{R^{2}=.011, F(1,240)=2.55\right.$; $\left.>.05\right\}$. This implies that gender was not critical in predicting civil servants' indulgence in procrastinating behaviour. It also means that, males and females civil servants were not significantly different in their indulgence in procrastinating behaviour.

Table 4: Summary of Independent t-Test Showing Influence of Marital Status on Indulgence in Procrastinating Behaviour

\begin{tabular}{|lccccc|}
\hline IPB. & $\mathrm{N}$ & $\bar{X}$ & $\mathrm{df}$ & $\mathrm{t}$ & $\mathrm{P}$ \\
\hline Single & 80 & 34.66 & & & \\
& & & 240 & 2.43 & $<.05$ \\
Married & 162 & 32.27 & & & \\
\hline
\end{tabular}

$* \mathrm{P}<.05, \mathrm{IPB}=$ Indulgence in Procrastinating Behaviour

Hypothesis four which stated that, there will be significant difference between single and married employees' in their indulgence in procrastinating behaviour was accepted $\{\mathrm{t}(240)=2.43$; $\mathrm{p}<$ $.05\}$. The results of Table 4 showed that, marital status had significant influence on employees' indulgence in procrastinating behaviour and that there single and married civil servants were significantly different in their indulgence in procrastinating behaviour. Observation of the mean scores further revealed that, single civil servants $(\bar{X}=34.66)$ indulged more significantly in procrastinating behaviour than married civil servants $\quad(\bar{X}=32.37)$. 
Predictors of Indulgence in Procrastinating Behaviour: Demographic Variables and Self-Esteem

Table 5: Summary of One-Way ANOVA Showing Influence of Educational Qualification on Indulgence in Procrastinating Behaviour

\begin{tabular}{lcclll}
\hline Source & SS & df & MS & F & P \\
\hline Between Groups & 591.41 & 4 & 147.85 & 2.93 & $<.05$ \\
Within Groups & 11813.85 & 234 & 50.49 & & \\
Total & 12405.26 & 238 & & & \\
& & & &
\end{tabular}

Table 5.1: LSD Multiple Comparison Showing the Effect of Educational Qualification on Indulgence in Procrastinating Behaviour

\begin{tabular}{|c|c|c|c|c|c|c|}
\hline \multirow[t]{2}{*}{ Variables } & \multirow[t]{2}{*}{$\bar{X}$} & \multicolumn{4}{|c|}{ Mean Difference } & \multirow[b]{2}{*}{5} \\
\hline & & 1 & 2 & 3 & 4 & \\
\hline 1. Primary & 33.67 & -- & & & & \\
\hline 2. Secondary & 34.95 & -1.29 & -- & & & \\
\hline 3. OND & 34.15 & -.48 & .81 & -- & & \\
\hline 4. HND/B.Sc. & 33.05 & .62 & 1.91 & 1.10 & -- & \\
\hline 5. M.Sc./PhD & 28.00 & 5.57 & $6.96 *$ & $6.15 *$ & $5.05 *$ & -- \\
\hline
\end{tabular}

*Mean is significant at 0.05 level

Hypothesis five which stated that, educational qualification will have a significant effect on employees' indulgence in procrastinating behaviour was confirmed $\{\mathrm{F}(4,234)=2.93 ; \mathrm{p}<.05\}$. This means that, educational attainment of the employees significantly affect their indulgence in procrastinating behaviour.

Furthermore, Table 5.1 revealed that, there was significant difference in indulgence in procrastinating behaviour between employees that possessed Secondary School Examination Certificate $(\bar{X}=34.95)$ and employees that had M.Sc./PhD degree $(\bar{X}=28.00)$ with mean difference of 6.96. Observation of the mean scores showed further that, employees that possessed Secondary School Examination Certificate $(\bar{X}=34.95)$ significantly indulged in procrastinating behaviour than employees that had M.Sc./PhD degree $(\bar{X}=28.00)$.

Likewise, Table 5.1 showed that, there was significant difference in indulgence in procrastinating behaviour between employees that, had Ordinary National Diploma Certificate $(\bar{X}=34.15)$ and employees that possessed M.Sc./PhD degree $(\bar{X}=28.00)$ with mean difference of 6.15. Observation of the mean scores also showed that, employees with Ordinary National 
Diploma Certificate $(\bar{X}=34.15)$ significantly indulged in procrastinating behaviour than employees with M.Sc./PhD degree $(\bar{X}=28.00)$.

Finally, Table 5.1 indicated that, there was significant difference in indulgence in procrastinating behaviour between employees that, possessed Higher National Diploma Certificate/B.Sc. degree $(\bar{X}=33.05)$ and employees with M.Sc./PhD degree $(\bar{X}=28.00)$ with mean difference of 5.05. Observation of the mean scores indicated that, employee with Higher National Diploma Certificate/B.Sc. degree $(\bar{X}=33.05)$ significantly indulged in procrastinating behaviour than employees with M.Sc./PhD degree $(\bar{X}=28.00)$.

Table 6: Summary of One-Way ANOVA Showing Influence of Work Experience on Indulgence in Procrastinating Behaviour

\begin{tabular}{|lccccc|}
\hline Source & SS & df & MS & F & P \\
\hline Between Groups & 390.35 & 4 & 97.59 & 1.90 & $>.05$ \\
Within Groups & 11799.50 & 230 & 51.30 & & \\
Total & 12189.85 & 234 & & & \\
& & & & & \\
$*$ & & & & & \\
& & &
\end{tabular}

Hypothesis six which stated that, work experience will have a significant effect on employees' indulgence in procrastinating behaviour was not supported $\{F(4,230)=1.90 ; p>.05\}$. Thus work experience did not have a significant effect on employees' indulgence in procrastinating behaviour.

Table 7: Summary of Multiple Regression Analysis using Self-esteem, Age, Gender, Marital Status, Educational Qualification, and Work Experience to predict Indulgence in Procrastinating Behaviour

\begin{tabular}{|c|c|c|c|c|c|c|c|c|}
\hline Predictors & & $\mathrm{R}$ & $\mathrm{R}^{2}$ & $\mathrm{~F}$ & $\mathrm{P}$ & $\beta$ & $\mathrm{t}$ & $\mathrm{P}$ \\
\hline Self-esteem & & & & & & -.21 & -3.30 & $<.001$ \\
\hline Gender & & & & & & -.09 & -1.34 & $>.05$ \\
\hline \multirow[t]{2}{*}{ Age } & & & & & & -.09 & -.81 & $>.05$ \\
\hline & .37 & .14 & 5.84 & $<.001$ & & & & \\
\hline Marital Status & & & & & & -.10 & -1.22 & $>.05$ \\
\hline Edu.Qulif. & & & & & & -.19 & -2.10 & $<.01$ \\
\hline Work Exp. & & & & & & -.04 & -.37 & $>.05$ \\
\hline
\end{tabular}


$* \mathrm{P}<.05 ; * * \mathrm{P}<.01 ; * * * \mathrm{P}<.001$, Edu Qulif. = Educational Qualification, Work Exp. = Work Experience

Hypothesis seven which stated that, Self-esteem, age, gender, marital status, educational qualification, and work experience will jointly predict employees' indulgence in procrastinating behaviour significantly was affirmed $\left\{\mathrm{R}^{2}=.14, \mathrm{~F}(6,215)=5.84 ; \mathrm{p}<.001\right\}$. The results imply that, Self-esteem, age, gender, marital status, educational qualification, and work experience jointly predicted employees' indulgence in procrastinating behaviour. The results also showed that, $14 \%$ variance in the sampled respondents' were jointly contributed by the predictors.

\section{DISCUSSION}

The study examined demographic variables and self-esteem as predictors of indulgence in procrastinating behaviour.

The analysis of results revealed that, self-esteem independently predicted employees' indulgence in procrastinating behaviour significantly. It was also showed that employees with low selfesteem indulged in procrastinating behaviour more significantly than employees with high selfesteem. These results imply that, the extent to which employee sees her or himself as a valuable and worthy individual is critical in explaining procrastinating behaviour. The findings of this research are in line with the findings of Adu and Shenge (2012) who found that, certain psychological factors (self-esteem, self-efficacy, and self-regulation) are significant in explaining indulgence in procrastinating behaviour. The results of this research are alike with the findings of Guindon (2010) who suggested that what individuals choose to do and the way they do it depend on their self-esteem. The results also re-echoed the findings of Steel (2011) who emphasized that impulsiveness and related traits such as low self-esteem, poor self-control and distractibility are core to procrastinating behaviour.

The hypothesis that stated that, employees' age will independently predict indulgence in procrastinating behaviour significantly was affirmed. The findings likewise revealed that, indulgence in procrastinating behaviour decrease with age. The reason for this may be that, as an employee increases in age, he/she becomes more adjusted, gets more realistic value and worth of self and better understanding of whatever (including employment) he/she is doing and as a result has little or no time to push forward what he/she is expected to do. The results of this study are in line with the findings of Steel (2007) who found that, procrastination appears to decrease with age $(r=-.15)$. Likewise it supports U.S. Census Bureau (2000) which found a significant negative relationship between age and procrastination. The finding also supports the finding of Steel and Ferrari (2013) who found that, procrastination tended to associate with the young people.

The hypothesis that stated that, there will be a significant difference between single and married employees' in their indulgence in procrastinating behaviour was accepted. It was likewise 
showed in the analysis of the results that, single employees significantly indulged in procrastinating behaviour more than married employees. The reason for this kind of results may be that, single employees may be having the feelings that, no children or intimate family members to distract them from doing whatever task they want to do at any point in time and as a result of this push forward what they ought to do now to a more "convenient time'". For the married employees, they may have the feelings that, pushing forward what they ought to do now to a more "convenient time" may be dangerous as children or spouse may not give them the opportunity to have that more "convenient time". This finding supports the finding of Steel and Ferrari (2013) who found that, procrastination is associated with single young men.

The hypothesis that stated that, educational qualification will have a significant effect on employees' indulgence in procrastinating behaviour was also confirmed and the results further revealed that, employees with Secondary School Certificate, OND, HND/B.SC degree significantly indulged in procrastinating behaviour more than employees with M.Sc./PhD degree. The reason for this may be that, employees with M.Sc./PhD degree had acquired sufficient professional/educational qualifications coupled with adequate career experiences which gave them enough mastery of their work assignments and as a result capable of performing their work duties without delay. The finding of this study is consistent with the finding of Steel and Ferrari (2013) who found a significant correction between procrastination and people with less education.

In order to examine the joint contribution of all of the predictor variables of interest to employees' indulgence in procrastinating behaviour, multiple regression analysis was performed. Self-esteem, age, gender, marital status, educational qualification, and work experience were entered into the regression equation. The regression model summarized in Table 7 accounted for $14 \%$ variance in indulgence in procrastinating behaviour. This finding is congruent with that of Steel and Ferrari (2013). Steel and Ferrari (2013) found that, procrastinating behaviour is associated with young, single men with less education residing in countries with lower levels of self-discipline.

\section{CONCLUSION}

In conclusion, the present study indicated that self-esteem is a predictor of indulgence in procrastinating behaviour. Thus it is important that, employees see themselves as worthy and valuable individuals in order to lessen their tendencies to indulge in procrastinating behaviour. Results from the study also suggest that, some demographic factors (e.g. gender, age, marital status, work experience, and educational qualification) are capable of predisposing employees to indulgence in procrastinating behaviour. Thus management and employers of labour should look for reasonable ways of balance things up in order to lessen, if not totally eliminating indulgence in procrastinating behaviour in their workforce. Management can achieve all of these by providing the employees with learning environment and also provide rooms for employees' training and development. This can come in form of allowing the employees to go for result oriented professional/educational training that would afford them (the employees) to acquire 
requisite skills that would be of tremendous help to performing their work assignments without delay.

\section{REFERENCES}

1. Akerlof, G., (1991), "Procrastination and Obedience," American Economic Review, 81, 119.

2.Akinsola, M. K. , Tella, A., Tella, A. (2007). Correlates of academic procrastination and mathematics achievement of university undergraduate students. Eurasia Journal of Mathematics, Science \& Technology Education, 3(4), 363-370.

3. Al-Mutairi, A. (2010). Factors Affecting Business Students' Performance in Arab Open University: The Case of Kuwait. International Journal of Business Management, 6(5), 146 $-155$.

4. Anderson, C. J. (2003). The psychology of doing nothing: Forms of decision avoidance result from reason and emotion. Psychological Bulletin, 129, 139-167.

5. Bandura, A. (1977). Social learning theory. Englewood Cliff s, NJ: Prentice-Hall.

6. Bandura, A. (1997). Self-efficacy: The exercise of control. New York: Freeman.

7. Beck, B. L., Koons, S. R., \& Milgrim, D. L. (2000). Correlates and consequences of behavioural procrastination: The effects of academic procrastination, self-consciousness, self-esteem and self-handicapping. Journal of Social Behaviour \& Personality, 15(5), 313.

8. Beswick, G., \& Mann, L. (1994). State orientation and procrastination. In procrastination: A structural equation model. Unpublished master's thesis, University of Guelph, Ontario, Canada.

9. Birder, L. (1993). Procrastination: Its role in transference and countertransference. Psychoanalytic Review, 80(4), 541-558.

10. Burka, J. B., \& Yuen, L. M. (1983). Procrastination: Why you do it, what to do about it. Reading, MA: Addison-Wesley.

11. Effert, B. R., \& Ferrari, J. R. (1989). Decisional Procrastination - Examining PersonalityCorrelates. Journal of Social Behaviour and Personality, 4(1)151-156.

12. Eggens, L., van der Werf, M. P. C., \& Bosker, R. J. (2008). The influence of personal networks and social support on study attainment of students in university education. Higher Education, 55(5), 553-573.

13. Ellis, A., \& Knaus, W. J. (1977). Overcoming procrastination. New York: Signet Books.

14. Feingold, A. (1994). Gender differences in personality: A meta-analysis. Psychological Bulletin, 116, 429-526.

15. Ferrari, J. R. (1993a). Christmas and procrastination: Explaining lack of diligence at a "real world" task deadline. Personality and Individual Differences, 14, 25-33.

16. Ferrari, J. R. (1994). Dysfunctional procrastination and Its relationship with self-esteem, interpersonal dependency, and self-defeating behaviours. Personality and Individual Differences, 17(5), 673-679. 
17. Ferrari, J. R. (2001). Procrastination and attention: Factor analysis of attention deficit, boredomness, intelligence, self-esteem, and task delay frequencies. Journal of Social Behaviour \& Personality, 16, 185-196.

18. Ferrari, J. R., Johnson, J. L., \& McCown, W. G. (1995). Procrastination and task avoidance: Theory, research, and treatment. New York: Plenum Press.

19. Ferrari, J. R., O'Callaghan, J. \& Newbegin, I. (2005). Prevalence of procrastination in the United States, United Kingdom, and Australia: Arousal and avoidance delays among adults. North American Journal of Psychology, 7(1), 1-6.

20. Ferrari, J.F. (2000). Procrastination and attention: Factor analysis of attention deficit, boredomness, intelligence, self-esteem, and task delay frequencies. Journal of Social Behaviour and Personality, 15, 185-196.

21. Flett, G. L., Blankstein, K. R., \& Martin, T. R. (1995). Procrastination, negative selfevaluation, and depression: A review and preliminary model. In J. Ferrari, J. Johnson \& W. McCown (Eds.), Procrastination and task avoidance: Theory, research, and treatment (pp. 137-167). NY: Plenum Press.

22. Freud, S. (1953). Inhibitions, symptoms and anxiety in collected works. London: Hogards.

23. Guindon, M. H. (2010). What is self-esteem? In M. H. Guindon (Ed.), Self-esteem: Across the life span.

24. Hammer, C. A., \& Ferrari, J. R. (2002). Differential incidence of procrastination between blue-collar and white-collar workers. Current Psychology: Developmental, Learning, Personality, Social, 21(4), 333-338.

25. Harriott, J., \& Ferrari, J. R. (1996). Prevalence of procrastination among samples of adults. Psychological Reports, 78(2), 611-616.

26. Howell, A. J., \& Watson, D. C. (2007). Procrastination: associations with achievement goal orientation and learning strategies. Personality and Individual Differences, 43, 167178.

27. Judge, T. A., \& Bono, J. E. (2001). Relationship of core self-evaluations traits - selfesteem, generalized self-efficacy, locus of control, and emotional stability - with job satisfaction and job performance: A meta-analysis. Journal of Applied Psychology, 86, 8092.

28. Klassen, R., Krawchuk, L. \& Rajani, S. (2008). Academic procrastination of undergraduates: Low self-efficacy to self-regulate predicts higher levels of procrastination. Contemporary Educational Psychology, 33, 915-931.

29. Klein, E. (1971). A comprehensive etymological dictionary of the English language. New York: Elsevier.

30. Knaus, W. J. (2000). Procrastination, blame, and change. Journal of Social Behaviour \& Personality, 15(5), 153-166.

31. Korman, A. K. (1970). Toward a hypothesis of work behavior. Journal of Applied Psychology, 54, 31-41.

32. Korman, A. K. (1976). Hypothesis of work behaviour revisited and an extension. Academy of Management Review, 1, 50-63. 
33. Lay, C. (1986). At last, my research article on procrastination. Journal of Research in Personality, 20, 474-495.

34. Lay, C. H., \& Silverman, S. (1996). Trait procrastination, anxiety, and dilatory behaviour. Personality and Individual Differences, 21, 61-67.

35. Lazarus, R.S., \& Folkman, S. (1984). Stress, appraisal, and coping. New York: Springer.

36. Milgram, N. A., Dangour, W., \& Raviv, A. (1991). Situational and personal determinants of academic procrastination. The Journal of General Psychology, 119(2), 123-133.

37. Oxford English reference dictionary (2nd ed.). (1996). New York: Oxford University Press.

38. Ozer, B. U. (2010). A path analytic model of procrastination: testing cognitive, affective, and behavioural components. An unpolished doctorate degree thesis, Middle East Technical University.

39. Popoola, B. I. (2005). A study of the relationship between procrastinatory behaviour and academic performance of undergraduate students in a Nigerian University. African Symposium: An online Journal of Educational Research Network. [Online] Available: http.//www2.

40. Rosenberg, M. J. (1965). When dissonance fails: On eliminating evaluation apprehension from attitude measurement. Journal of Personality and Social Psychology, 1, 28-43.

41. Silver, M., \& Sabini, J. (1981). Procrastinating. Journal for the Theory of Social Behaviour, 11, 207-221.

42. Smith, J., \& Naylor, R. (2001). Determinants of degree performance in UK universities: a statistical analysis of the 1993 cohort. Oxford Bulletin of Economics and Statistics, 63(1), 29-60.

43. Solomon, L. \& Rothblum, E. (1984). Academic procrastination: Frequency and cognitive behavioural correlates. Journal of Counseling Psychology, 31(4), 503-509.

44. Steel, P. (2007). The nature of procrastination: A meta analytic and theoretical review of quintessential self-regulatory failure. Psychological Bulletin, 133(1), 65-94.

45. Steel, P. (2011). Uitstel gedrag: waarom we lastige dingen voor ons uit schuiven en hoe we hiervan afkomen [The Procrastination Equation: How to Stop Putting Things Off and Start Getting Stuff Done]. Amsterdam, The Netherlands: Ten Have.

46. Steel, P. and Ferrari, J. (2013). Sex, education and procrastination: An epidemiological study of procrastinators' characteristics from a global sample. European Journal of Personality, 27(1), 51-58.

47. Tice, D. M. (1991). Esteem protection or enhancement: Self-handicapping motives and attributions differ by trait self-esteem. Journal of Personality and Social Psychology, 60(5), 711-725.

48. Tuckman, B. W. (1991). The development and concurrent validity of the Procrastination Scale. Educational and Psychological Measurement, 51, 473-480.

49. U.S. Census Bureau. (2000). Midyear population, by age and sex. Retrieved January 4, 2014, from http://www.census.gov/ipc/www/idbconf.html. 